\title{
球圧子接触繰返し荷重下でのセラミックス被覆材におけるはく離発生挙動 Delamination behavior of ceramic film under cyclic contact loading by sphere indenter
}

\author{
正 滋賀県立大学 高松徹 正 滋賀県立大学 田邊 裕貴 $\bigcirc$ 学 滋賀県立大学院 田島 俊宏 \\ Tohru TAKAMATSU Hirotaka TANABE \\ Toshihiro TAJIMA \\ The University of Shiga Prefecture, Hassaka-cho 2500, Hikone,Shiga
}

Key Words: Coating Material, Surface Improvement, Residual Stress, Cyclic Contact, TiN Film, Fracture Strength, Delamination, Sphere Indentation Test, Ring Crack.

\begin{abstract}
バイアス電圧を変えて $\mathrm{dc}$ マグネトロンスパッタ法により TiN 薄膜をコーティングした工具鋼 SK3 を用いて，球 圧子径 $2 R$, 最大荷重 $P_{\max }$ を変えた条件で球圧子繰返し荷重負荷試験を行った，その結果以下のことが分かっ た，(1)静的荷重では薄膜にリングクラックが発生しない荷重でも，繰返し負荷すると球圧子接触領域の若干外側 の薄膜にき裂・はく離を生じる。(2)発生したき裂はリングクラックの一部であり，き裂とはく離はほぼ同時に発 生する. (3)はく離発生寿命 $N_{\mathrm{d}}$ は $P_{\max }$ の低下に従って増加し, $P_{\max }-N_{\mathrm{d}}$ 関係は $2 R$ 依存性を示す. 同じ $N_{\mathrm{d}}$ と なる $P_{\max }$ は $2 R$ が大きい方が大きい. (4) $P_{\max }$ から求めたき裂発生位置での半径方向の引張応力 $\sigma_{\mathrm{r}, \mathrm{d}}$ と $N_{\mathrm{d}}$ 関係 の $2 R$ 依存性は， $P_{\max }-N_{\mathrm{d}}$ 関係に比べて小さい。(5) $N_{\mathrm{d}}$ は $V_{\mathrm{B}}$ が小さい方が大きい.
\end{abstract}

\section{1. まえがき}

筆者らはこれまで，セラミック被覆材におう薄膜の破壊強 度，および破壊じん性評価に対する球圧子押込み試験法の有 効性について検討した(1),(2)。球圧子押込み試験法は，セラミ ック被覆材に球圧子を静的に押付け，荷重を増加した場合の薄 膜のリングクラック(半径方向の引張応力によって生じる円状のき 裂)発生現象を利用するものである.セラミック被覆金属基板に 球圧子を押込むと基板は塑性変形を示すが，硬さが大きな基 板で，大きさが比較的大きな球圧子の場合，基板の塑性変形 は小さい状態でリングクラックが発生する。 その場合, 近似的に 弾性接触応力および応力拡大係数が適用でき，基板硬さによ らない絶対的評価が可能である.ただし, 球径を変えた場合, ぜい性材料の寸法効果の影響も予想されるので，確率論的手 法などを用いて, 球压子径に依存しない特性値を推定するこ とも必要である．さらに，一般に薄膜には成膜時に大きな圧 縮残留応力を生じることがあるので, 残留応力を考慮した推 定も必要である.筆者らはこれまで, TiN 被覆超硬合金(WC-Co 基板)を試験片として, 球径を広範囲に変えた球圧子押込み試 験を行い, 薄膜の破壊強度を推定し, 破壊強度に及ぼす成膜 時のバイアス電圧の影響を明らかにした。そその結果, 球圧子 押込み試験法の有効性はある程度明らかとなったが，硬さが 小さい基板に対しては塑性変形が大きくなり，球径を大きく してもリングクラックが発生しないため適用できない。しかし， そのような硬さの小さい基板に被覆した薄膜に対しても，低 い荷重を長時閒繰返し負荷することにより，薄膜に破壊やは く離が生じる可能性がある。そこで本研究では, 筆者らの球 圧子押込み試験法に関する研究の一環として, 球圧子を用い て繰返し接触荷重を加えた TiN 被覆 SK3 鋼の薄膜の破壊およ びはく離挙動に及ぼす球圧子径, 荷重, およびバイアス電圧 の影響を明らかにすることを目的とした。

\section{2. 実験方法}

基板には, SK3 炭素工具鋼を用いた。これを所定の寸法 $(20$ $\times 40 \times 5 \mathrm{~mm})$ に加工し, 真空焼入れ後に焼もどし処理を行っ た。 その後, 耐水エメリー紙井2000を用いて研磨仕上げを行 った結果, 算術平均粗さは約 $0.05 \mu \mathrm{m}$ となった. ビッカース硬 さは約 HV800であった．基板制作後， dc マグネトロンスパッ夕リ ング装置を用いて TiN 薄膜を成膜し試験片とした。膜厚は約 $2.5 \mu \mathrm{m}$, バイアス電圧は $V_{\mathrm{B}}=0,-60 \mathrm{~V} の 2$ 通りとした。これ までの筆者らの研究 ${ }^{(1)} よ り, V_{\mathrm{B}}$ を変えることにより, 膜硬さ, 残留応力, 膜組織が変化することが明らかになっているので, 本研究ではその結果を参考に $V_{\mathrm{B}}$ を決定した。球圧子接触繰

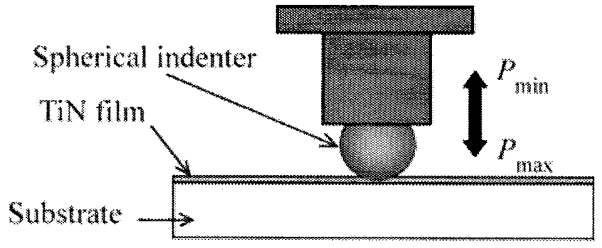

Fig.1 Schematic of cyclic loading sphere indenter test

返し荷重下の試験の概略を図 1 に示す。試験は油圧サーボ式 疲労試験機を用い, 荷重制御, 荷重比 0.1 , 周波数 $50 \mathrm{~Hz}$ の条 件で行った。球圧子には軸受用 HIP 焼結 $\mathrm{Si}_{3} \mathrm{~N}_{4}$ 球を用いた.

球圧子径 $2 R$ は, 筆者らの球圧子押込み試験で用いていた 3.96 , 7.93，9.6 mm の3 種類とした。 WC-Co 基板を用いた前報 ${ }^{(1)} の$ 球圧子押込み試験におけるリングクラック発生荷重は,

$2 R=3.96 \mathrm{~mm}$ では約 $4 \mathrm{kN}, 2 R=7.93 \mathrm{~mm}$ では約 $8 \mathrm{kN}, 2 R=9.6 \mathrm{~mm}$ では約 $10 \mathrm{kN}$ である. 本研究の TiN 被覆 SK3 鋼に静的荷重を 負荷した結果，いずれの $2 R$ においてもリングクラックは発生し なかった。 そこで, WC-Co 基板におけるリングクラック発生荷 重の約 20〜30\%を最大荷重 $P_{\max }$ として繰返し荷重負荷試験を 行った。試験中，一定の回数（約 30000 回）ごとに試験を中 断して，接触領域を観察した。観察には，デジタルマイクロス コープ，および走査型電子顕微鏡 SEMを用いた。

\section{3. 実験結果および考察}

3. 1 はく離発生挙動 接触領域の観察の結果, 初期の段階 では，くぼみのみが観察されたが，ある繰返し数でき裂およ びはく離が観察できた。き裂，はく離の例を図 2 に示す。図 2 は, $P_{\max }=1.6 \mathrm{kN}, 2 R=7.93 \mathrm{~mm}, V_{\mathrm{B}}=-60 \mathrm{~V}$, 繰返し数 $N=3 \times$ $10^{5}$ 回の場合である。図 2 (a) より接触領域の周辺にき裂が生 じており，一部ではく離が生じているのが分かる.図 2(b)は， 図 2 (a)のはく離箇所周辺(A 部分)を SEMにより観察した結果

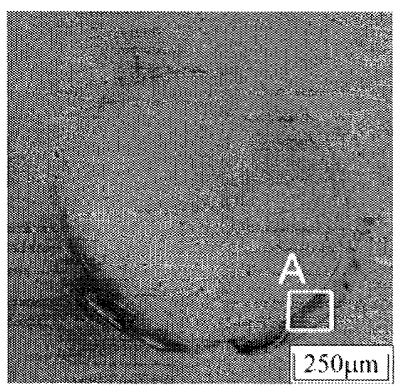

(a)

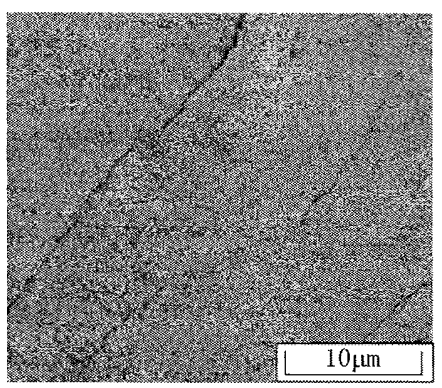

(b)
Fig.2 Example of ring crack 
である. 図 2(b)よりはく離箇所周辺にもき裂が発生している のがわかる。このことから, 図 2 (a)におけるはく離は薄膜表 面に発生したき裂が原因で生じたと考えられる。なお，本研 究における接触領域の観察からは, き裂発生とはく離発生は ほぼ同時であることがわかった。

図 3 は，図 2 のき裂部分を高倍率で観察した結果である. 図 3 より,き裂は結晶粒界にそって進展しているのがわかる。 き裂の微視的様相は, 前報 ${ }^{(1)}$ における球圧子押込み試験でのリ ングクラックの様相と同様である，そのことから，本研究で観 察されたき裂は，部分的なリングクラックと考えられる.

以上の様相は, 他の条件の場合も同様であった.すなわち, 静的荷重では発生しない荷重であっても, 長時間繰返し負荷 することによって，薄膜にリングクラック，およびはく離を 生じることがわかる。しかし, き裂, はく離の発生メカニズ ムに関しては現時点では不明であり，今後の課題である。

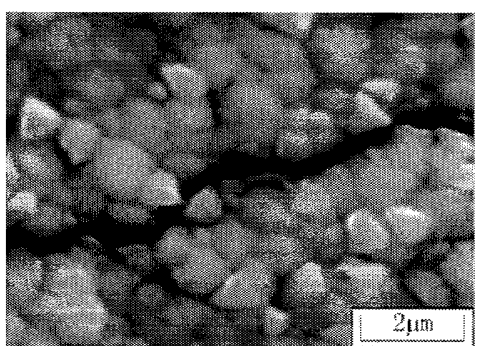

Fig.3 Microstructure of ring crack

\section{2 はく離発生寿命に及ぼす球圧子径の影需}

図 4 に, $2 R$ を変えた場合の $P_{\max }$ とはく離発生繰返し数 $N_{\mathrm{d}}$

(対数目盛) の関係を示す $\left(V_{\mathrm{B}}=-60 \mathrm{~V}\right)$. 図 4 より, いずれの $2 R$ の場合も $N_{\mathrm{d}}$ は $P_{\max }$ の低下に伴って, ほぼ直線的に増加し ている.そこで, $2 R$ ごとに直線近似した. 図 4 より, 同じ $N_{\mathrm{d}}$ となる $P_{\max }$ は $2 R$ が大きい方が大きいことがわかる.また， $2 R=3.96 \mathrm{~mm}$ と $9.6 \mathrm{~mm}$ の場合を比較すると， $P_{\max }$ に倍近くの 違いがあることがわかる。すなわち， $P_{\max }-N_{\mathrm{d}}$ 関係の $2 R$ 依 存性は明確である。

前報 ${ }^{(2)}$ の球圧子押込み試験では，リングクラック発生強度 $\sigma_{\mathrm{r}, \mathrm{i}}$ を, リングクラック発生位置での膜の半径方向の引張応力 $\sigma_{\mathrm{r}, \mathrm{d}}$ と して求めた. そこで, 本研究でも前報 ${ }^{(2)}$ と同一の式を用いて, 次式で示すように, $P_{\max }$ からき裂発生位置における膜の半径 方向の引張応力 $\sigma_{\mathrm{r}, \mathrm{d}}$ を求めた.

$$
\sigma_{r, d}=\frac{E_{f}\left(1+v_{s}\right)}{E_{s}\left(1+v_{f}\right)} \cdot \frac{1-2 v_{s}}{2} \cdot \frac{P_{\max }}{\pi r_{f}{ }^{2}}
$$

ここで $E$ : ヤング率, $v$ : ポアソン比, $P_{\max }$ : 最大荷重, $r_{\mathrm{f}}$ :リ ングクラック半径（き裂発生位置）であり，添え字の $\mathrm{f}, \mathrm{s}$ 注そ れぞれ薄膜，基板を示す。

図 5 に, $2 R$ を変えた場合の $\sigma_{\mathrm{r}, \mathrm{d}}-N_{\mathrm{d}}$ の関係を示す。図より

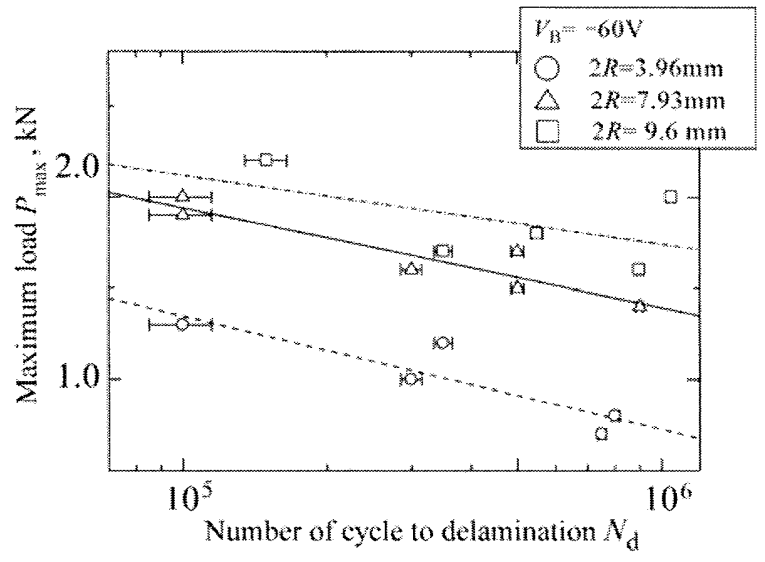

Fig.4 Influence of $2 R$ on the $P_{\max }-N_{\mathrm{d}}$ relationship

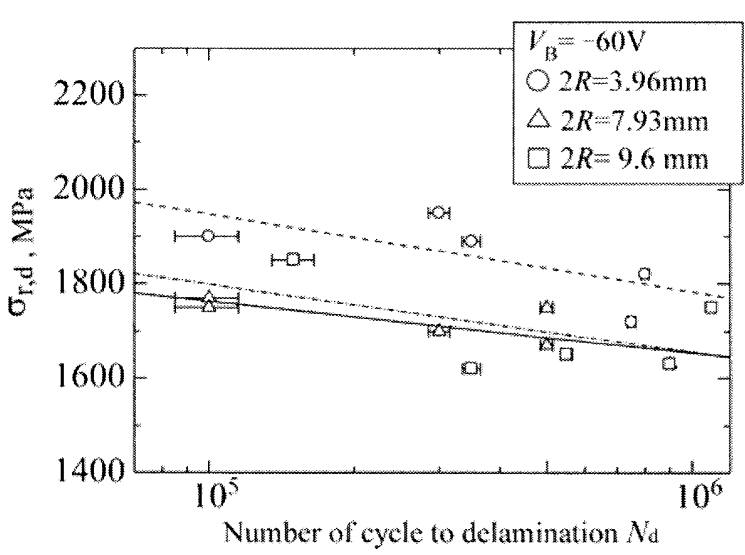

Fig5 Influence of $2 R$ on the $\sigma_{\mathrm{r}, \mathrm{d}}-N_{\mathrm{d}}$ relationship

いずれの $2 R$ も， $\sigma_{\mathrm{r}, \mathrm{d}}$ が小さくなるに伴って $N_{\mathrm{d}}$ は長くなる傾 向が見られる。ささらに， $\sigma_{\mathrm{r}, \mathrm{d}}-N_{\mathrm{d}}$ 関係は約 $10 \sim 15 \%$ の範囲にあ ることから， $\sigma_{\mathrm{r}, \mathrm{d}}-N_{\mathrm{d}}$ 関係に及ぼす $2 R$ の影響は， $P_{\max }-N_{\mathrm{d}}$ 関 係の場合に比べて小さいといえる.

ただし， $2 R=3.96 \mathrm{~mm}$ の $\sigma_{\mathrm{r}, \mathrm{d}}$ に関しては，他の $2 R$ より大きな 值を示寸傾向が見られる.その原因としては塑性変形の影響 及びぜい性材料の破壊強度の寸法効果の影響が考えられる。

\section{3 はく離発生寿命に及ほすバイアス電圧の影霖}

図 6 に, $\sigma_{\mathrm{r}, \mathrm{d}}-N_{\mathrm{d}}$ 関係に及ぼす $V_{\mathrm{B}}$ の影響を示す $(2 R=7.93 \mathrm{~mm})$. 図より, $N_{\mathrm{d}}$ は $V_{\mathrm{B}}=0 \mathrm{~V}$ の方が $V_{\mathrm{B}}=-60 \mathrm{~V}$ より若干大きい傾向を 示すことがわかる。この原因として，薄膜の残留态力および 結晶粒径の影響が考えられる。前報 ${ }^{(1)} よ り ， V_{\mathrm{B}}$ の増加に伴っ て，薄膜の圧縮残留応力は増加する傾向を示すことがわかっ ている $\left(V_{\mathrm{B}}=0 \mathrm{~V}\right.$ でほぼゼロ, $V_{\mathrm{B}}=-60 \mathrm{~V}$ で約 $\left.2.0 \mathrm{GPa}\right)$. 従って, 残留応力の観点からは， $N_{\mathrm{d}}$ は $V_{\mathrm{B}}=-60 \mathrm{~V}$ の方が大きくなるこ とが予想され，今回の $N_{\mathrm{d}}$ の相違は説明できない，一方，前報 (1)より， $V_{\mathrm{B}}$ の増加に伴い結晶粒径は増加する傾向を示すこと がわかっており，本研究の観察結果も同様であった（ $V_{\mathrm{B}}=0 \mathrm{~V}$ で約 $0.3 \mu \mathrm{m}, V_{\mathrm{B}}=-60 \mathrm{~V}$ で約 $\left.0.8 \mu \mathrm{m}\right)$ 。一般に，破壊強度は結晶 粒径が小さいほど増加すると予想されるので, $N_{\mathrm{d}}$ に及ぼす $V_{\mathrm{B}}$ の影響は，定性的には結晶粒径の影響として説明できる。

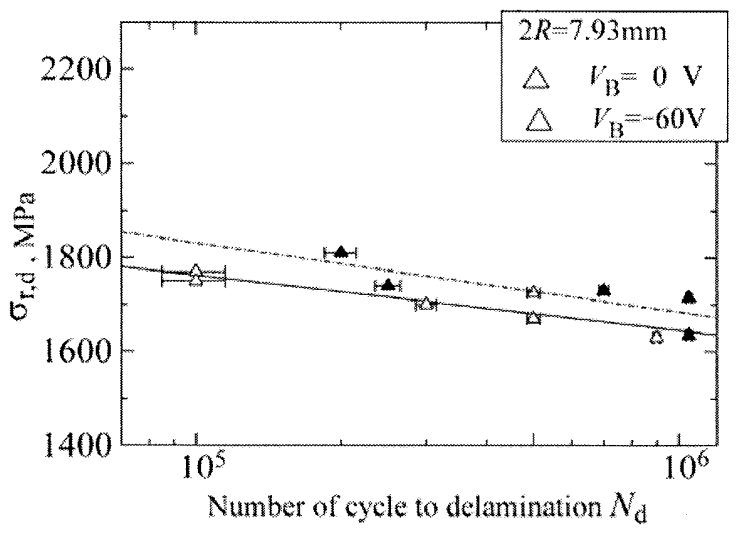

Fig.6 Influence of $V_{\mathrm{B}}$ on the $\sigma_{\mathrm{r}, \mathrm{d}}-N_{\mathrm{d}}$ relationship

\section{4. まとめ}

・静的荷重ではリングクラックが発生しない荷重でも，繰返し負 荷すると球圧子接触領域の若干外側の薄膜にき裂・はく離を 生じる。

・発生したき裂はリングクラックの一部であり，き裂とはく離は ほぼ同時に発生する。

・はく離発生寿命 $N_{\mathrm{d}}$ は $P_{\max }$ の低下に従って増加し, $P_{\max }-N_{\mathrm{d}}$ 関係は $2 R$ 依存性を示し, 同じ $N_{\mathrm{d}}$ となる $P_{\max }$ は $2 R$ が大き い方が大きい。

- $P_{\max }$ から求めた膜に生じたき裂位置の半径方向の引張応力 $\sigma_{\mathrm{r}, \mathrm{d}}$ と $N_{\mathrm{d}}$ 関係の $2 R$ 依存性は, $P_{\max }-N_{\mathrm{d}}$ 関係に比心゙て小さい. 